\title{
Preimplantation Genetic Diagnosis for Brca1 and Brca2 Mutations
}

\author{
Brca1 ve Brca2 Mutasyonları için Preimplantasyon Genetik Tanı
}

\author{
Yavuz Emre Șükür1', Batuhan Özmen², Cem Somer Atabekoğlu²
}

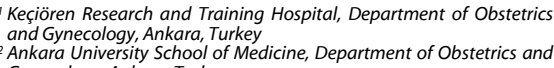

2 Ankara University School of Medicine, Department of Obstetrics and Gynecology, Ankara, Turkey

Received : July 13, 2015• Accepted: July 11, 2016

Corresponding Author

Uz. Dr. Yavuz Emre Șükür

E-mail:yesukur@yahoo.com, yesukur@gmail.com Ankara Keçiören Research and Training Hospital Department of Obstetrics and Gynecology

\begin{abstract}
Hereditary breast and ovarian cancer syndrome is an inherited cancer-susceptibility syndrome with multiple family members with breast cancer or ovarian cancer or both, the presence of both breast cancer and ovarian cancer in a single individual, and early age of breast cancer onset. BRCA1 and BRCA2 tumor suppressor gene mutations are responsible for the vast majority of inheritance of breast and ovarian cancers. Approximately $10 \%$ of ovarian cancer patients and approximately 3-5\% of breast cancer patients have predominating BRCA1 and BRCA2 gene mutations. Preimplantation genetic diagnosis (PGD) is an alternative to conventional prenatal diagnostic techniques such as amniocentesis and chorionic villus sampling. Prenatal diagnosis for BRCA mutation in an ongoing pregnancy and pregnancy termination brings some ethical and psychological questions together. Hence, it may be favorable to perform PGD for patients with BRCA mutations. Eventually, PGD may be recommended at least to the infertile patients with BRCA mutation who should already undergo in vitro ifertilization IVF (in vitro fertilization).

Key Words: BRCA1/2 Mutations; Hereditary Breast and Ovarian Cancer; in Vitro Fertilization; Preimplantation Genetic Diagnosis

Herediter meme ve over kanseri sendromu meme, over veya her ikisinin birden kanserine sahip birden fazla aile üyesinin bulunduğu, bir bireyde hem meme hem de over kanserinin görüldüğü, ve erken bașlangıçlı meme kanseri görülen kalıtsal bir kanser yatkınlık sendromudur. Meme ve over kanseri kalıtımının büyük çoğunluğundan BRCA1 ve BRCA2 tümör süpresör gen mutasyonları sorumludur. Over kanserlerinin yaklașık $\% 10$ 'unda ve meme kanserlerinin yaklașık \%3-5'inde büyük oranda BRCA1 ve BRCA2 mutasyonları görülür. Preimplantasyon genetic tanı (PGT) amniyosentez ve koryon villüs örneklemesi gibi geleneksel prenatal tanı tekniklerinin bir alternatifidir. Devam etmekte olan bir gebelikte BRCA mutasyonunun prenatal teshis edilmesi ve gebeliğin sonlandırılması konusu beraberinde bazı etik ve psikolojik soruları da tașımaktadır. Bu nedenle, BRCA mutasyonu olanlarda PGT uygulanması daha uygun olabilir. Nihayetinde, PGT en azından BRCA mutasyonu olan ve zaten IVF uygulanacak infertil hastalara önerilebilir.

Anahtar Sözcükler: BRCA1/2 Mutasyonları; Herediter Meme ve Over Kanseri; in Vitro Fertilizasyon; Preimplantasyon Genetik Tanı
\end{abstract}

Preimplantation genetic diagnosis is a recent and emerging technique with its advantages and disadvantages. Although the true indications for this new technique are still controversial, it may be very helpful in prevention of some mortal diseases such as inherited late onset cancers. Hereditary breast and ovarian cancer syndrome is an inherited cancer-susceptibility syndrome with multiple family members with breast cancer or ovarian cancer or both, the presence of both breast cancer and ovarian cancer in a single individual, and early age of breast cancer onset. BRCA1 and BRCA2 tumor suppressor gene mutations are responsible for the vast majority of inheritance of breast and ovarian cancers. Approximately 10\% of ovarian cancer patients and approximately $3-5 \%$ of breast cancer patients have predominating BRCA1 and BRCA2 gene mutations. Although being BRCA1/2 mutation carrier just expresses an increased cancer risk, some ethical issues arise about the prenatal diagnosis. Preimplantation genetic diagnosis gives the chance of selecting embryos without BRCA1/2 mutations. But, for a fertile couple this procedure brings an exhausting and expensive in vitro fertilization attempt together. However, preimplantation genetic diagnosis may be a good option for infertile BRCA1/2 mutation carriers who are already candidates for in vitro fertilization. 


\section{Preimplantation Genetic Diagnosis and Genetic Counseling}

Preimplantation genetic testing refers to a technique for prenatal diagnosis of cytogenetic and mendelian disorders via biopsy of one or two cells from an in vitro embryo at the 6 to 8 cell stage (developmental day 3) or from a polar body $(1,2)$. The term preimplantation genetic diagnosis (PGD) is used when testing is performed to identify a known heritable chromosomal abnormality or a gene mutation. PGD is an alternative to conventional prenatal diagnostic techniques such as amniocentesis and chorionic villus sampling. The advantage of PGD is avoidance of intrauterine transfer of affected embryos. It may have additional value for improving pregnancy rates associated with assisted reproductive technologies (ART), as well as screening for genetic problems not conventionally associated with invasive prenatal diagnostic techniques.

There are some disadvantages of PGD compared to conventional prenatal diagnostic methods. Even if the couple is fertile, In Vitro Fertilization (IVF) is required to conceive when PGD is the choice. In Vitro Fertilization (IVF) is an expensive, exhausting and time consuming procedure and has some risks, such as ovarian hyperstimulation syndrome and multiple pregnancies. In addition, fetal structural anomalies not associated with cytogenetic or single gene disorders are not detected by PGD, but can often be identified by sonography performed in conjunction with conventional prenatal diagnostic methods.

\section{Indications for Preimplantation Genetic Diagnosis}

Potential indications for PGD include avoidance of pregnancy termination with an affected child, preselection of HLA type to permit treatment of a sibling by cord blood transfusion or bone marrow transplantation, sex selection, improvement of ongoing pregnancy rates and detection of structural chromosomal abnormalities and single gene disorders. The expanding identification of genes and proteins associated with particular diseases, syndromes, conditions, and phenotypes are pushing the current barriers and limitations of PGD. The technique has already been used to screen for mutations associated with certain heritable cancers and for predisposition to early-onset Alzheimer disease $(3,4)$, uncommon indications for conventional prenatal testing.

Preimplantation genetic diagnosis involving IVF and embryo biopsy was developed to prevent pregnancies affected with serious life-threatening genetic diseases. It has been used for high penetrance recessive disorders like cystic fibrosis and $\beta$-thalassaemia, dominant disorders like Huntington's disease and myotonic dystrophy and $\mathrm{X}$-linked disorders like Fragile $\mathrm{X}$ and Duchenne muscular dystrophy which occur early in life and for high penetrance cancer syndromes like familial adenomatous polyposis coli and multiple endocrine neoplasia that occur later in life (5).

Recently there has been a debate about extending the use of PGD to include lower penetrance, late onset cancer susceptibility syndromes such as hereditary breast and ovarian cancer (HBOC) (6). Genetic counseling and testing for breast and ovarian cancers are mainly concerning the oncologic care, but some important questions regarding cancer risk for themselves and their siblings particularly daughters, the benefits of genetic testing, and the efficacy of management options for those at increased risk remain unanswered. A critical issue is determining which patients' daughters are most likely to harbor gene mutations that can be identified by genetic testing. In May 2006, the UK Human Fertilization and Embryology Authority (HFEA) decided that in principle it was appropriate for PGD to be available for HBOC. A family history of breast or ovarian cancer, particularly before the age of 50 years in a first order relative, and Ashkenazi Jewish ancestry are risk factors for BRCA1 or BRCA2 mutations.

\section{Hereditary Breast and Ovarian Cancer}

Hereditary breast and ovarian cancer syndrome is an inherited cancersusceptibility syndrome. The hallmarks of this syndrome are multiple family members with breast cancer or ovarian cancer or both, the presence of both breast cancer and ovarian cancer in a single individual and onset of breast cancer at early ages.

One of the most important risk factors for breast and ovarian cancers is family history. A positive family history significantly increases a woman's risk for breast cancer. $20-30 \%$ of women with breast cancer have at least one relative with the disease $(7,8)$. However, the majority of women with a positive family history do not have "hereditary" breast cancer. Most hereditary breast cancers arise from mutations in the genes BRCA1 and BRCA2, which are inherited in an autosomal dominant fashion and thought to function as tumor suppressor genes 0 .

Just like breast cancer, inherited genetic mutations are thought to be associated with $10 \%$ of women with ovarian cancer. The hereditary ovarian cancer as well as breast cancer is mainly due to BRCA1 and BRCA2 gene mutations. Germline mutations in BRCA1 and BRCA2 account for the vast majority of families with hereditary breast and ovarian cancer syndrome. Approximately $10 \%$ of cases of ovarian cancer and $3-5 \%$ of cases of breast cancer are due to mutations in BRCA1 and BRCA2 $(9,10)$. Carriers were predicted to have at least 15fold age-specific risk of ovarian cancer compared with non-carriers (11). The estimated risk was $2 \%$ by the age of 50 years and $16 \%$ by the age of 70 years compared with the non-carrier risk of $0.4 \%$ by 50 years and $1.6 \%$ by 70 years (12).

\section{BRCA1 and BRCA2 Mutations}

BRCA1 is located on the long arm of chromosome $17 \mathrm{q}$, and BRCA2 is located on chromosome 13q12. More than 2500 different mutations have 
been reported for BRCA1 and BRCA2. BRCA1 and BRCA2 are tumor suppressor genes that encode proteins that function in the DNA repair process. Although individuals with hereditary breast and ovarian cancer syndrome inherit one defective allele in BRCA1 or BRCA2 from their father or mother, they have a second, functional allele. If the second allele becomes nonfunctional, cancer can develop through the accumulation of additional mutations. This situation is called as the "two-hit hypothesis" (13).

In general population, the incidence of BRCA mutations is between $1 / 300$ and $1 / 800$ (14). For a woman with a BRCA1 mutation, the risk of ovarian cancer is $39-46 \%$. For a woman with a BRCA2 mutation, the risk of ovarian cancer is $12-20 \%$. The estimated lifetime risk of breast cancer with a BRCA1 or BRCA2 mutation is 65$74 \%(15,16)$. For women with breast cancer, the 10 -year risk of developing ovarian cancer is $12.7 \%$ for BRCA1 mutation carriers and $6.8 \%$ for BRCA2 mutation carriers (17). Ovarian cancer associated with BRCA1 and BRCA2 mutations has a distinct histological phenotype; predominantly of high grade serous or endometrioid histology (18). Primary fallopian tube and primary peritoneal

\section{REFERENCES}

1. Verlinsky Y, Rechitsky S, Verlinsky O, et al. Preimplantation diagnosis for sonic hedgehog mutation causing familial holoprosencephaly. N Engl J Med. 2003; 348: 1449-1454.

2. Harper JC, Bui TH. Pre-implantation genetic diagnosis. Best Pract Res Clin Obstet Gynaecol 2002; 16: 659-670.

3. Verlinsky Y, Rechitsky S, Verlinsky O, et al. Preimplantation diagnosis for earlyonset Alzheimer disease caused by V717L mutation. JAMA. 2002; 287: 1018-1021.

4. Spits C, De Rycke M, Van Ranst N, et al. Preimplantation genetic diagnosis for cancer predisposition syndromes. Prenat Diagn 2007; 27: 447-456. cancer also are part of the spectrum of disease associated with BRCA1 and BRCA2 mutations (19).

\section{PGD for BRCA Gene Mutations}

BRCA mutation carriers have a 50\% chance for the inheritance of cancer predisposition mutation. There are some choices for healthy relatives of cancer patients and young breast cancer survivors to prevent this inheritance: avoid having children, ovum donation (or sperm donation in case of male carriers), prenatal diagnosis, or PGD. In two different studies attitudes or decisions of BRCA mutation carriers were researched. In the first study, $75 \%$ of 52 patients with BRCA mutation found PGD acceptable (5). However, in the second study $13 \%$ of 213 patients with BRCA mutation stated PGD was considerable (20).

In clinical practice, there are only a few reports on PGD for BRCA mutations. Jasper et al. (21) performed PGD for a 31 year-old BRCA1 mutation carrier who was already infertile for 3 years. Recently, Sagi et al. (22) reported their data on PGD for BRCA mutations. 10 BRCA1/2 mutation carriers, that 8 of them were already infertile, applied for PGD counseling. 6 patients accepted PGD and 5 of them underwent PGD for
BRCA mutations and 3 patients were conceived each in the first attempt (22). In the total of these two reports IVF was required due to coexisting infertility for 9 of 11 patients. Fertile couples would be more reluctant to enter into an IVF procedure, especially having learned about the limited success rate, the potential risks involved in ovulation induction, and the high cost. The balance between advantages and disadvantages of PGD obviously differs between fertile and infertile couples. However, some fertile women/couples might seriously consider this option depending on other factors, such as a very strong family history of cancer, and surviving breast cancer that occurred at a very young age (22).

On the other hand, prenatal diagnosis for BRCA mutation in an ongoing pregnancy and termination of the pregnancy for a BRCA mutation carrier fetus brings some ethical and psychological questions together. Although it is not acceptable to terminate the pregnancy for a BRCA mutation carrier fetus, it may be favorable to perform PGD for patients with BRCA mutations. Eventually, PGD may be recommended at least to the infertile patients with BRCA mutation who should already undergo IVF.
5. Menon U, Harper J, Sharma A, et al. Views of BRCA gene mutation carriers on preimplantation genetic diagnosis as a reproductive option for hereditary breast and ovarian cancer. Hum Reprod 2007; 22: 1573-1577.

6. Robertson JA. Extending preimplantation genetic diagnosis: the ethical debate. Ethical issues in new uses of preimplantation genetic diagnosis. Hum Reprod 2003; 18: 465-471.

7. Slattery ML, Kerber RA. A comprehensive evaluation of family history and breast cancer risk. JAMA 1993; 270: 1563-1568.

8. Claus EB, Risch NJ, Thompson WD. Age at onset as an indicator of familial risk of breast cancer. Am J Epidemiol 1990; 131: 961-972.
9. Risch HA, McLaughlin JR, Cole DE, et al. Population BRCA1 and BRCA2 mutation frequencies and cancer penetrances: a kin-cohort study in Ontario, Canada. J Natl Cancer Inst. 2006; 98: 1694-1706.

10. Rubin SC, Blackwood MA, Bandera C, et al. BRCA1, BRCA2, and hereditary nonpolyposis colorectal cancer gene mutations in an unselected ovarian cancer population: relationship to family history and implications for genetic testing. Am J Obstet Gynecol 1998; 178: 670-677.

11. Copeland LJ. Epithelial Ovarian Cancer. In: Disaia PJ, Creasman WT. Clinical Gynecologic Oncology. Philadelphia, Mosby Elsevier Press, 2007; 313-367.

12. Struewing JP, Hartge P, Wacholder S, et al. The risk of cancer associated with spe- 
cific mutations of BRCA1 and BRCA2 among Ashkenazi Jews. $\mathrm{N}$ Engl J Med. 1997; 336: 1401-1408.

13. Knudson AG Jr. Mutation and cancer: statistical study of retinoblastoma. Proc Natl Acad Sci USA 1971; 68: 820-823.

14. Whittemore AS, Gong G, Itnyre J. Prevalence and contribution of BRCA1 mutations in breast cancer and ovarian cancer: results from three U.S. population-based casecontrol studies of ovarian cancer. Am J Hum Genet 1997; 60: 496-504.

15. Antoniou A, Pharoah PD, Narod S, et al. Average risks of breast and ovarian cancer associated with BRCA1 or BRCA2 mutations detected in case series unselected for family history: a combined analy- sis of 22 studies.Am J Hum Genet 2003; 72: 1117-1130.

16. King MC, Marks JH, Mandell JB. Breast and ovarian cancer risks due to inherited mutations in BRCA1 and BRCA2. New York Breast Cancer Study Group. Science 2003; 302: 643-646.

17. Metcalfe KA, Lynch HT, Ghadirian P, et al. The risk of ovarian cancer after breast cancer in BRCA1 and BRCA2 carriers. Gynecol Oncol 2005; 96: 222-226.

18. Lakhani SR, Manek S, Penault-Llorca F, et al. Pathology of ovarian cancers in BRCA1 and BRCA2 carriers. Clin Cancer Res 2004; 10: 2473-2481.

19. Levine DA, Argenta PA, Yee CJ, et al. Fallopian tube and primary peritoneal carcinomas associated with BRCA mutations. J Clin Oncol 2003; 21: 4222-4227.

20. Staton AD, Kurian AW, Cobb K, et al. Cancer risk reduction and reproductive concerns in female BRCA1/2 mutation carriers. Fam Cancer 2008; 7: 179-186.

21. Jasper MJ, Liebelt J, Hussey ND. Preimplantation genetic diagnosis for BRCA1 exon 13 duplication mutation using linked polymorphic markers resulting in a live birth. Prenat Diagn 2008; 28: 292 298.

22. Sagi M, Weinberg N, Eilat A, et al. Preimplantation genetic diagnosis for BRCA1/2-a novel clinical experience. Prenat Diagn 2009; 29: 508-513. 